\title{
Pollen productivity estimates from KwaZulu-Natal Drakensberg, South Africa
}

\author{
Trevor R. Hill \& Tristan J. Duthie ${ }^{1}$ \\ Discipline of Geography, School of Agriculture, Earth and Environmental \\ Science, University of KwaZulu-Natal, Pietermaritzburg, South Africa
}

Jane Bunting

Department of Geography, Geology and Environment, University of Hull, Hull, United Kingdom

\begin{abstract}
Pollen assemblages from sedimentary sequences reflect the landscapes surrounding the basin at the time of deposition, however the translation of pollen records into estimates or maps of past landcover is complex. Models of the pollen-vegetation relationship can help, but need to be calibrated first against modern data on pollen and vegetation for the pollen types of interest. This study presents initial estimates of Relative Pollen Productivity in the KwaZulu-Natal Drakensberg, South Africa, a palaeoecologically significant region of southern Africa, using the Extended R-Value approach. Modern pollen spectra from soil surface samples were extracted from three dominant vegetation communities, and vegetation data were collected around each sample point using a 3-tiered ring surveying approach. Fall speeds of key taxa were calculated using Stokes Law for spherical pollen grains and Falck's assumption for ellipsoidal grains. Pollen and vegetation data were subjected to Extended R-value analysis to calculate Relevant Source Area of Pollen (RSAP) and Relative Pollen Productivity estimates (RPP). RSAPs were found to be approximately 100-150 $\mathrm{m}$ in all three communities. Asteraceae and Proteaceae have low RPPs relative to Poaceae, the RPP of Ericaceae is comparable to Poaceae, and Pteridophyte spores and Rosaceae and Podocarpaceae pollen have significantly higher RPP values than Poaceae. These results imply that the cover of some important shrub taxa may well be underestimated in palaeoecological records from the area relative to forested communities. The number of modern pollen samples collected and analysed was small, and therefore these results can only be considered initial estimates, however they demonstrate that it is possible to use soil surface samples to obtain RSAP and PPE estimates in this important ecological and cultural region of southern Africa.
\end{abstract}

\subsection{INTRODUCTION}

A key aim of Quaternary palynology investigations is the quantitative reconstruction of past vegetation (Broström 2002; Sugita 2007a). A quantified understanding of the relationship between pollen assemblages retrieved at a site and the surrounding vegetation provides a sound basis for quantitative reconstruction of past environments (Jackson 1994). Plants have a range of growth

\footnotetext{
${ }^{1}$ Other affiliation: University of Suwon, South Korea
} 
forms and reproductive strategies, and these lead to differences in the amount of pollen produced by equivalent amounts of plant and to the dispersal potential of those pollen grains. This means pollen diagram interpretation is complicated (Jackson 1994; Prentice 1988); despite recent developments, much of the interpretation of pollen diagrams remains subjective and based on intuition. The challenge thus faced by contemporary palynologists has been to develop and supply the study of pollen analysis with improved tools for quantifying past vegetation and reconstruction techniques of palaeoenvironments (Räsänen et al. 2007).

There are three main approaches to the reconstruction of past land cover from pollen data: biomisation, modern analogue approaches and modelling the pollen-vegetation relationship. Biomisation approaches convert pollen data into plant functional types, then use ratios of these types to identify the biomes present in past landscapes (Jolly et al. 1998; Vincens et al. 2006), combining sites to map past land cover at biome level across regions and continents. Modern analogue approaches take spatially extensive datasets of modern pollen assemblages and associated environmental parameters (e.g. climate factors such as precipitation or mean annual temperature, or indices of landcover), develop transfer functions or other mathematical models such as the CREST model (e.g. Chevalier et al. 2014), then apply these models to pollen records to reconstruct the proxies of interest for the duration of the record (e.g. Chevalier et al. 2021). Both approaches assume that modern biomes/ecosystems, and therefore the pollen assemblages derived from them, are comparable with those present in past landscapes. As pollen is widely dispersed in the landscape from the original plants, pollen assemblages reflect both the local environment and the wider region, often referred to as a source of 'background' pollen. This 'background' component can make up 40-60\% of the pollen influx recorded in a small lake or wetland (Sugita 1994), and whilst nature reserves and areas with lower human occupation may protect ecosystems which strongly resemble past conditions, the wider landscape has been heavily modified. The pollen-vegetation relationship modelling approach aims to address this concern by understanding how the pollen signal is formed, developing models of the relationship which are parameterised against modern data. The most widely used models of the pollen-vegetation relationship are linear, building on the R-value approach suggested by Davis (1963) (Andersen 1970; Davis 1963; Prentice 1985; Sugita 1993; reviewed by Jackson and Lyford 1999). This approach assumes that the pollen-vegetation relationship is constant in time, but is explicitly designed to reconstruct landcover options which have no modern analogues (Sugita 2007a 2007b; Bunting and Middleton 2009). This paper calibrates one such model for the main plant taxa found today in the KwaZulu-Natal Drakenberg, South Africa.

In the pollen-vegetation modelling approach, plants and their signal in a pollen assemblage are connected through models of pollen dispersal and deposition (Abraham and Kozáková 2012; Bunting 2008; Bunting and Hjelle 2010; Davis 2000). Using the modelling approach allows reconstruction of both abundance and spatial distribution of past vegetation (e.g. Broström 2002; Gaillard et al. 2008; Prentice 1985; Sugita 2007a, 2007b). The development of modern models of pollen dispersal and deposition has been reviewed by many authors and is not considered further here (e.g. Davis 2000; Li et al. 2018). The linear models used depend on estimates of Relative Pollen Productivity (RPP) and pollen fallspeed for the taxa of interest, and over the last 20 years, sets of these parameters have been developed for many regions of Europe and China (e.g. Abraham and Kozáková 2012; Broström et al. 2004; Bunting et al. 2005; Hjelle 1998; Li et al. 2018; Mazier et al. 2008; Mazier et al. 2012; Nielsen 2003; Räsänen et al. 2007; Soepboer et al. 2007; Sugita et al. 1999; von Stedingk et al. 2008). To date, there has been one such study published from Africa, in which Duffin and Bunting (2008) calculated RSAP and RPP estimates for southern Africa savanna taxa in the Savanna Biome of the Kruger National Park; a second such paper is included in this volume (Githumbi et al.).

The aim of this study was to obtain estimates of pollen productivity in the KwaZulu-Natal Drakensberg, to extend the range of taxa available for model use in South Africa and as a first step towards land cover reconstruction in the wider region, in order to strengthen the quality and 


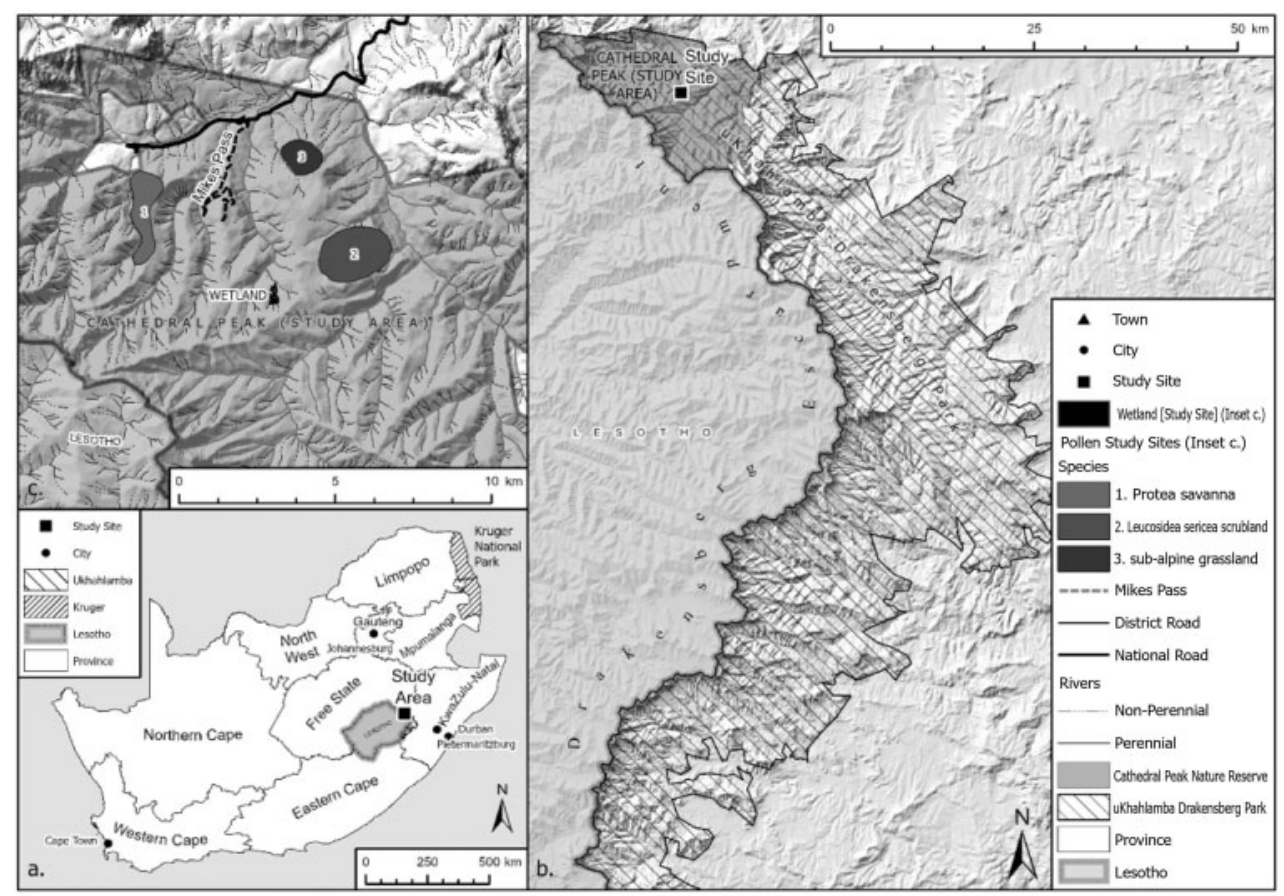

Figure 1. Location of Cathedral Peak study site in relation to: (a) orovinces and geographic features of South Africa, (b) the Drakensberg mountains in KwaZulu-Natal, and (c) kocal geographic features. Note: the wetlands highlighted in part c are those referred to in the study mentioned in the text by Lodder et al. (2018).

reliability of interpretations of long term palaeoecological records and improve the usefulness of palaeoecological data for allied disciplines such as conservation and archaeology.

\subsection{MATERIALS AND METHODS}

\subsubsection{Study site}

The study was carried out in the Cathedral Peak region of the KwaZulu-Natal Drakensberg $\left(28^{\circ} 56^{\prime} 26^{\prime \prime} \mathrm{S}, 29^{\circ} 14^{\prime} 06^{\prime \prime} \mathrm{E}\right)$ (Figure 1). The Drakensberg mountain range is an ecologically important area of South Africa with a number of archaeological and palaeo-ecological records, and is therefore a significant area of study (Mitchell and Lane 2013). The vegetation shows a strong altitudinal progression from Drakensberg Foothill Moist Grassland to Northern Drakensberg Highland Grassland, then to uKhahlamba Basalt Grassland and finally, Drakensberg Afro-alpine Heathland at the highest altitudes (Mucina and Rutherford 2011).

Three vegetation communities were focused on for this study; Themeda dominated Highland Sourveld (Acocks, 1988) that will be referred to as Themeda grassland, Protea savanna and Leucosidea sericea scrubland. These three communities are the dominant vegetation communities represented in the region, contain between them the plants producing the major pollen types seen in palaeoecological-records, and occupy different altitudinal climate zones, therefore changes in the distribution of these communities are expected in response to environmental change (Hill 1996). The range of altitudes sampled varies between 1300-2000 $\mathrm{m}$ asl mean annual rainfall in this altitudinal range fluctuates between $700-1500 \mathrm{~mm}$, and predominately falls in the summer months between October and March. 


\subsubsection{Methods}

A suite of standard methods were applied to collect and analyse the data required (Figure 2).

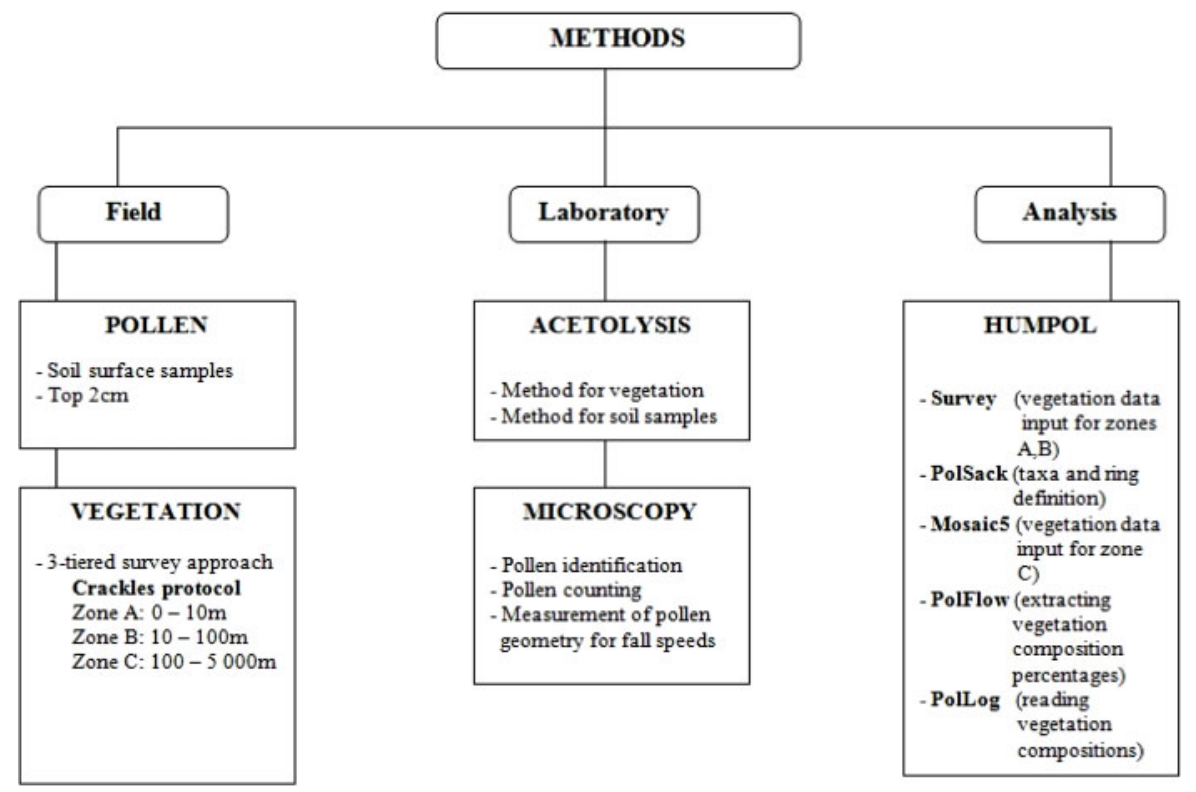

Figure 2. Schematic breakdown of methods used in this research: Field, Laboratory and Analysis.

\subsubsection{Field methods}

A total of five samples in each of the three vegetation communities were randomly located using ArcGIS 10.2, giving a total of 15 sample sites. Random positioning of sample locations is important wherever possible to obtain reliable RSAP and RPP estimates (Broström et al. 2005; Mazier et al. 2008). The central sampling point was located within a geo-rectified aerial photograph of the site, and locations in the field were found using a hand-held Garmin eTrex 10 GPS. At each sample site, the upper $2 \mathrm{~cm}$ of surface soil was collected following the methods described by Adam and Mehringer (1975) and Bunting et al. (2013) for collection of modern pollen surface samples. Vegetation surveys were carried out using a 3-tiered surveying approach, known as the Crackles vegetation protocol (Bunting et al. 2013), which was developed to standardise vegetation data collection for model calibration and thereby facilitate comparison of results between modelling studies. The vegetation surveying method is partitioned into three zones $(A, B, C)$, with a comprehensive vegetation survey undertaken in zone $A(0-10 \mathrm{~m}$ from the sample point), an intermediate vegetation survey in zone B $(10-100 \mathrm{~m})$, and GIS and remote sensing techniques used to extract broad-scale vegetation data from maps in zone $\mathrm{C}(100-1000+\mathrm{m})$.

\subsubsection{Laboratory methods}

Soil surface samples were processed following standard chemical extraction methods as described by Moore et al. (1991) and Duffin and Bunting (2008) at the University of KwaZulu-Natal (UKZN) Palaeoecology laboratory. Count size was determined by initially processing one soil surface sample from each of the vegetation communities, counting the pollen and recording the results with increasing sum size, and carrying out an 2-way Analysis of Variance (ANOVA) to assess if there was any significant difference in assemblages between sample counts of 250, 500 and 1000 pollen grains in each community (Sokal and Rohlf 1969). In all three communities 
it was found that no statistically significant difference existed between the population means of pollen counts of 250, 500 and 1000 at the level of significance $(\alpha=0.05)$, therefore remaining samples were counted to a sum of 250 grains (Hill 1996). All counting was conducted at x630 magnification using a Leica DM750 light microscope, with reference to the African Pollen database and UKZN Pollen repository specific to the region.

\subsubsection{Data analysis}

\subsubsection{Estimating pollen fall speed}

To use the taxon-specific Prentice-Sutton distance-weighting model to the vegetation data, estimates of the sedimentation velocity of the pollen types are required. An estimation method based on grain shape and size was used (e.g. Duffin and Bunting 2008). Pollen grains were categorised into two shape classes - spherical and ellipsoidal. Pollen grain geometries were measured using a Leica DM750 light microscope at $\times 400$ magnification. Spherical grains were measured along one axis only, recording a diameter measurement, whereas ellipsoidal grains were measured along major and minor axes. For each taxon, a total of 50 random pollen grains were measured from pollen reference slides collected in the region, and an average diameter (spherical) and major and minor axis (ellipsoidal) measurement calculated. Fall speed was estimated using Stokes Law for spherical grains (Equation 1) and Falck's Assumption for ellipsoidal grains (Equation 2) (Gregory 1973).

$$
v_{s}=\frac{2 r^{2} \cdot g\left(\rho_{0}-\rho\right)}{9 \mu} \text { Equation 1. Stokes Law }
$$

where:

$\mathrm{v}_{\mathrm{s}}=$ spherical settling velocity $\left(\mathrm{cm} \mathrm{s}^{-1}\right)$

$\mathrm{r}=$ pollen grain radius $(\mathrm{cm})$

$\mathrm{g}=$ acceleration due to gravity constant taken as $981 \mathrm{~cm} \mathrm{~s}^{-2}$

$\rho_{\mathrm{o}}=$ grain density $\left(\mathrm{cm}^{-3}\right)$ taken as $1 \mathrm{~cm}^{-3}$

$\rho=$ air density $\left(\mathrm{cm}^{-3}\right)$ taken as $1.27 \times 10^{-3} \mathrm{~cm}^{-3}$

$\mu=$ dynamic viscosity $\left(\mathrm{cm}^{-1} \mathrm{~s}^{-1}\right)$ taken as $1.8 \times 10^{-4} \mathrm{~cm}^{-1} \mathrm{~s}^{-1}$

$$
v_{e}=v_{s} \sqrt[3]{\frac{a}{b}} \text { Equation 2. Falck's Assumption }
$$

where:

$$
\begin{aligned}
& \mathrm{v}_{\mathrm{e}}=\text { ellipsoidal settling velocity }\left(\mathrm{cm} \mathrm{s}^{-1}\right) \\
& \mathrm{v}_{\mathrm{s}}=\text { spherical settling velocity }\left(\mathrm{cm} \mathrm{s}^{-1}\right) \\
& \mathrm{a}=\text { major axis }(\mathrm{cm}) \\
& \mathrm{b}=\text { minor axis }(\mathrm{cm})
\end{aligned}
$$

\subsubsection{Distance weighting vegetation data}

Distance weighting of vegetation data is necessary before comparing vegetation with pollen assemblages formed at a specific location, so as to account for the empirical observation that plants situated closer to a sampling location contribute more pollen than those situated further away. This study used the Prentice-Sugita distance weighting term (Prentice 1985, 1988; Sugita 1993), which assumes aerial transport of pollen above the vegetation canopy is the mode of connection between plant and pollen assemblage. Vegetation data were collated into rings and distance weighted plant abundance (dwpa) calculated using the ring-based approach described in the Crackles vegetation protocol (Bunting et al. 2013). 
The Prentice-Sugita-Sutton weighting term $\mathrm{g}_{i}$ for taxon $\mathrm{i}$ at distance $\mathrm{z}$ is calculated as:

$$
g_{i}(z)=b_{i} \gamma z^{\gamma-1} e^{b_{i} z^{\gamma}} \quad \text { Equation } 3
$$

where

$$
b_{i}=\frac{4 v_{g}}{n u \sqrt{\pi} C_{z}} \quad \text { Equation 3a }
$$

and,

$$
\begin{aligned}
& \mathrm{z}=\text { distance } \\
& \gamma=\text { a coefficient of } 0.125 \text { (Prentice } 1985) \\
& \mathrm{v}_{\mathrm{g}}=\text { approximated by } \mathrm{v}_{\mathrm{s}} \text { (fall speed, } \mathrm{m} \mathrm{sec}^{-1} \text { ) } \\
& \mathrm{C}_{\mathrm{z}}=\text { the vertical diffusion coefficient }\left(\mathrm{m}^{1 / 8}\right) \\
& \mathrm{n}=\text { a dimensionless turbulence parameter equal to } 2 \\
& \mathrm{u}=\text { windspeed }\left(\mathrm{m} \mathrm{sec}^{-1}\right) \text {, set equal to } 3 .
\end{aligned}
$$

\subsubsection{Extended R-value analysis (ERV)}

Extended R-value analysis is an iterative computational approach to estimating values of relative pollen productivity from a bivariate dataset of modern pollen counts and distance-weighted vegetation abundance (Parsons and Prentice 1981; Prentice and Parsons 1983). By applying this analysis to vegetation data surveyed out to different distances from the sample point, it is possible to assess the spatial sensitivity of the pollen signal in the samples (by identifying the Relevant Source Area of Pollen - Sugita 1994), which provide the best estimates of relative pollen productivity (RPP - amount of pollen produced per unit vegetation, expressed as a ratio relative to a reference taxon) for the studied landscapes and can inform the spatial interpretation of past land cover around pollen sites with similar characteristics.

On examination of the pollen counts and vegetation data, it was clear that the species lists of the three communities were too different to allow all 15 samples to be analysed together, therefore data analysis was carried out separately for each community. It is generally recommended that the number of samples included in an analysis should be at least twice the number of pollen taxa considered (Bunting and Hjelle 2010), however this was not possible in this study. All pollen taxa recorded as present in both the pollen and vegetation data from all five samples in each community were included in the analysis, and ERV analyses were run using the HUMPOL (Hull Method of Pollen dispersal and deposition model) software suite on each of the vegetation communities separately to estimate RSAP (Relevant Source Area of Pollen, the distance beyond which adding additional vegetation survey data does not improve the fit between data and model) and to calculate RPP values for dominant taxa from each community. ERV analysis was run using sub-models 1 and 2 only, as these models use pollen and vegetation percentage data (as was collected in this research), whereas sub-model 3 was not used as it requires absolute vegetation data (Gaillard et al. 2008).

ERV model 1 assumes a taxon-specific background pollen component for each taxon $i$ that is constant relative to the total influx of pollen at a site (Parsons and Prentice, 1981), whereas ERV model 2 assumes a taxon-specific background pollen component for each taxon $i$ that is a constant relative to the total plant abundance around a site (Prentice and Parsons, 1983). ERV model 3 was proposed by Sugita (1994) and can be utilised if pollen proportion and absolute plant abundance data are available, which it is not for this study. Gaillard et al. (2008) suggest that similar results should be obtained from the different ERV models if the background pollen loading is low relative to the total pollen loading at a sampling site. Broström (2002) points out that there is no apparent motive for choosing ERV model 1 over 2 (or vice versa) a priori, and that both should be used simultaneously to see if they provide comparable model outputs (i.e. relative pollen productivity $\alpha_{i}$ and background pollen component $\mathrm{z}_{\mathrm{i}}$ to deduce their robustness). 


\subsubsection{Application of RPP estimates to palaeoecology}

One published pollen record is available from the study area, an unnamed small wetland within the management catchment called 'catchment six' (c. 0.1 ha - see Figure 1) (Lodder et al. 2018). The small size of the site and lack of other nearby sites means that full reconstruction of past landcover using the Landscape Reconstruction Algorithm (Sugita 2007a; b) is not appropriate, since this method relies on the availability of multiple pollen sites. The Multiple Scenario Approach (e.g. Bunting et al. 2018) could be applied to a single small site, however it is time-consuming and will be considered for future research. As a simple demonstration of how RPP values can be used to inform interpretation of pollen diagrams, therefore, we have undertaken a simple correction, taking no account of background pollen influx. Using count data for the taxa listed in Table 1, we summed data into a single sample for each pollen zone then calculated unweighted and weighted pollen percentages for comparison. Weightings were calculated as follows:

$$
p_{i w}=\frac{n_{i} / R_{i}}{\sum_{m}^{1} n_{j} / R_{j}} \quad \text { Equation 4. Simple weighting }
$$

where

$\mathrm{p}_{\mathrm{iw}}$ is the weighted proportion of taxon $\mathrm{i}$

$\mathrm{n}_{\mathrm{i}}$ is the count of grains of taxon $\mathrm{i}$

$R_{i}$ is the $R P P_{\text {Poaceae }}$ value for taxon $i$

$\mathrm{m}$ is the number of taxa for which $\mathrm{RPP}_{\text {Poaceae }}$ values are available.

Table 1. Palynological equivalent taxa identified from Cathedral Peak. Shown are the ten most prevalent taxa for all sample sites.

\begin{tabular}{|c|c|c|c|c|c|c|c|c|c|c|c|}
\hline \multirow[b]{2}{*}{$\begin{array}{l}\text { Vegetation } \\
\text { Community }\end{array}$} & \multirow[b]{2}{*}{$\begin{array}{l}\text { Sub- } \\
\text { sample } \\
\text { number }\end{array}$} & \multicolumn{10}{|c|}{ Percentage of pollen sum $(\%)$} \\
\hline & & 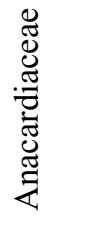 & 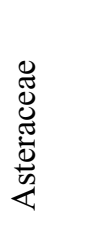 & 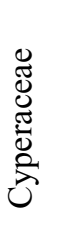 & 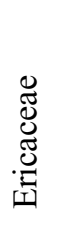 & $\begin{array}{l}\mathfrak{\Xi} \\
\vdots \\
\vdots\end{array}$ & 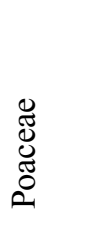 & 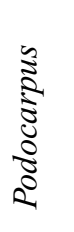 & 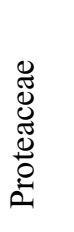 & 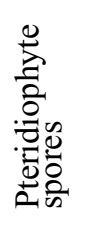 & 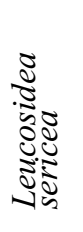 \\
\hline \multirow{5}{*}{$\begin{array}{l}\text { Themeda } \\
\text { grassland }\end{array}$} & 1 & 2.68 & 9.96 & 2.30 & 0.00 & 1.15 & 55.17 & 0.00 & 0.00 & 5.75 & 0.00 \\
\hline & 2 & 1.18 & 10.20 & 1.96 & 0.39 & 3.53 & 60.78 & 0.00 & 0.00 & 14.12 & 0.00 \\
\hline & 3 & 0.00 & 8.95 & 2.72 & 0.00 & 1.95 & 62.26 & 1.17 & 0.00 & 14.79 & 0.00 \\
\hline & 4 & 0.79 & 7.91 & 2.77 & 0.00 & 1.98 & 67.98 & 0.79 & 0.40 & 9.88 & 0.00 \\
\hline & 5 & 0.78 & 5.08 & 4.30 & 0.39 & 3.52 & 73.05 & 0.78 & 0.00 & 5.47 & 0.00 \\
\hline \multirow{5}{*}{$\begin{array}{l}\text { Protea } \\
\text { savanna }\end{array}$} & 1 & 0.00 & 6.25 & 0.00 & 0.39 & 5.08 & 57.81 & 2.34 & 9.38 & 11.33 & 0.00 \\
\hline & 2 & 0.79 & 3.56 & 9.49 & 0.40 & 1.19 & 54.94 & 1.19 & 6.32 & 8.30 & 0.00 \\
\hline & 3 & 0.39 & 4.28 & 3.50 & 0.00 & 2.33 & 56.81 & 0.39 & 8.17 & 14.40 & 0.00 \\
\hline & 4 & 1.20 & 3.19 & 2.79 & 0.40 & 1.20 & 41.83 & 0.80 & 5.58 & 36.25 & 0.00 \\
\hline & 5 & 0.39 & 5.43 & 3.88 & 1.94 & 3.88 & 46.12 & 1.94 & 9.69 & 15.89 & 0.00 \\
\hline \multirow{5}{*}{$\begin{array}{l}\text { Leucosidea } \\
\text { sericea } \\
\text { scrubland }\end{array}$} & 1 & 0.79 & 15.75 & 3.54 & 0.79 & 2.36 & 47.24 & 0.00 & 0.00 & 11.42 & 10.63 \\
\hline & 2 & 0.00 & 18.33 & 3.19 & 1.99 & 1.59 & 54.98 & 0.00 & 0.00 & 9.56 & 2.79 \\
\hline & 3 & 0.39 & 24.02 & 2.36 & 1.97 & 1.57 & 41.73 & 0.00 & 0.00 & 14.17 & 1.57 \\
\hline & 4 & 0.40 & 14.68 & 3.97 & 1.59 & 0.79 & 44.84 & 0.00 & 0.00 & 25.79 & 2.38 \\
\hline & 5 & 1.20 & 14.34 & 3.59 & 1.20 & 0.00 & 44.62 & 0.00 & 0.00 & 20.32 & 1.99 \\
\hline
\end{tabular}




\subsection{RESULTS}

\subsubsection{Vegetation data}

Poaceae is the dominant vegetation cover type in all three studied vegetation communities, interspersed with shrubs and herbs (Asteraceae, Ericaceae, Euphorbiaceae, Fabaceae, Rubiaceae and Thymelaeaceae species). Bracken fern (Pteridium aquilinum (L.) Kuhn) is omnipresent throughout all vegetation communities. The Themeda grassland primarily consisted of Poaceae and small herbs and shrubs of Acanthaceae (Barleria monticola), Asteraceae (Helichrysum aureonitens, Vernonia natalensis, Senecio coronatus), Euphorbiaceae (Acalypha punctata), and Fabaceae (Eriosema simulans). Predominant woody vegetation cover was in the form of patchy indigenous Podocarpus type forest in all communities. Higher altitudes and valley areas along river courses are dominated by scrub vegetation which was particularly evident in the Leucosidea and Protea communities. Proteaceae (Protea caffra, P. roupelliae) was scattered throughout the Protea community, which is otherwise dominated by grasses and shrubs. Rosaceae (Leucosidea sericea) was pervasive throughout the Leucosidea community; vegetation in this landscape was dominated by grasses, ferns and Leucosidea sericea, a woody species that will invade un-burnt grassland.

\subsubsection{Pollen data}

Forty palynological equivalent taxa were identified from a total of 15 samples (Table 1 and 2). All samples had high proportions of Poaceae pollen (40-70\%). The Themeda grassland community samples consistently contained Pteridophyte spores (5-15\%), and herbaceous Asteraceae pollen (5-10\%). Anacardiaceae, Cyperaceae and Pinaceae pollen grains were recorded in significant quantities. Anacardiaceae can be explained by the omnipresence of Searsia dentata shrubs throughout the Themeda grassland landscape and Cyperaceae reflects the presence of aquatic-type environments, explained by a nearby wetland and stream system close to all Themeda samples. The presence of exotic Pine is interesting considering the closest known Pinaceae plantation is approximately $7 \mathrm{~km}$ away, however isolated pine trees were observed invading nearby surrounding grasslands. Samples from Protea savanna communities contained Pteridophyte spores (10-40\%), Proteaceae (5-10\%) and Asteraceae (6\%) pollen. The Leucosidea scrubland samples have substantial proportions of Asteraceae (10-25\%) pollen and Pteridophyte spores (5-25\%), and lower of Rosaceae $(10 \%)$, Ericaceae $(<2 \%)$ and Cyperaceae $(5 \%)$ pollen values.

\subsubsection{Data analysis}

Taxa chosen for ERV analysis of samples from the Themeda grassland were Poaceae, Pteridophyta and Asteraceae, ERV analysis from the Protea savannah included Poaceae, Pteridophyta, Asteraceae, Proteaceae and Podocarpaceae, and ERV analysis from the Leucosidea shrubland included Poaceae, Pteridophyta, Ericaceae, and Rosaceae. Outcomes of ERV analysis (using both ERV model 1 and 2) show that all communities have a RSAP range of 100-150 m, suggesting that the local vegetation cover has a strong influence in the pollen spectra (Figure 3 ). Plots of likelihood function score reach an asymptote approximately $100-150 \mathrm{~m}$ from sample points (Figure 3). While RSAP values from sub-model 1 and 2 were similar, Relative Pollen Productivity values were markedly different, and the model which produced the most strongly clustered RPP values was chosen as the most appropriate one for each habitat (Broström 2002); this was ERV sub-model 1 in all three cases (Table 3). RPP Poaceae $_{\text {(pollen productivity relative to }}$ Poaceae) values were calculated by averaging all ERV analysis estimates from distances beyond $150 \mathrm{~m}$. 
Table 2. Shape, diameter and fall speeds of dominant taxa, Cathedral Peak.

\begin{tabular}{|c|c|c|c|c|c|}
\hline Cathedral Peak taxa & & $\begin{array}{l}\text { Approx. } \\
\text { shape }\end{array}$ & $\begin{array}{l}\text { Avg. } \\
\text { diameter } \\
(\mu \mathrm{m})\end{array}$ & $\begin{array}{l}\text { Fall } \\
\text { speed } \\
\left(\mathrm{m} \cdot \mathrm{s}^{-1}\right)\end{array}$ & $\begin{array}{l}\text { Avg. } \\
\text { fall speed } \\
\left(\mathrm{m} \cdot \mathrm{s}^{-1}\right)\end{array}$ \\
\hline Poaceae & $\begin{array}{l}\text { Themeda triandra } \\
\text { Alloteopsis semialata } \\
\text { Digitaria flaccida } \\
\text { Panicum natalensis } \\
\text { Tristachya leucothrix }\end{array}$ & Spherical & $\begin{array}{l}50.98 \\
33.91 \\
37.44 \\
30.78 \\
46.67\end{array}$ & $\begin{array}{l}0.079 \\
0.035 \\
0.042 \\
0.029 \\
0.066\end{array}$ & 0.050 \\
\hline Asteraceae & $\begin{array}{l}\text { Aster bakeranus } \\
\text { Helichrysum aureonitens } \\
\text { Vernonia type }\end{array}$ & $\begin{array}{l}\text { Spherical } \\
\text { Spherical }\end{array}$ & $\begin{array}{l}33.21 \\
20.16 \\
32.62\end{array}$ & $\begin{array}{l}0.033 \\
0.012 \\
0.032\end{array}$ & 0.026 \\
\hline Cornaceae & Curtisia dentata & Spherical & 16.89 & 0.009 & 0.009 \\
\hline Ebenaceaea & Diospyros austro-africana & Spherical & 48.32 & 0.071 & 0.071 \\
\hline Ericaceae & $\begin{array}{l}\text { Erica drakensbergensis } \\
\text { Erica cerinthoides } \\
\text { Erica straussianna }\end{array}$ & Spherical & $\begin{array}{l}33.24 \\
65.97 \\
47.05\end{array}$ & $\begin{array}{l}0.033 \\
0.132 \\
0.067\end{array}$ & 0.077 \\
\hline Euphorbiaceae & Acalypha punctata & Spherical & 15.48 & 0.007 & 0.007 \\
\hline Fabaceae & Eriosema simulans & Spherical & 36.81 & 0.041 & 0.041 \\
\hline Geraniaceae & Pelargonium type & Spherical & 91.77 & 0.255 & 0.255 \\
\hline Rubiaceae & Pentanisia prunelloides & Spherical & 42.12 & 0.054 & 0.054 \\
\hline Thymelaeaceae & Gnidia kraussiana & Spherical & 25.79 & 0.020 & 0.020 \\
\hline Pteridophyte spores & Pteridium aquilinum & & 38.18 & 0.044 & 0.044 \\
\hline Proteaceae & $\begin{array}{l}\text { Protea caffra } \\
\text { Protea roupillae }\end{array}$ & Spherical & $\begin{array}{l}23.38 \\
24.45\end{array}$ & $\begin{array}{l}0.017 \\
0.018\end{array}$ & 0.018 \\
\hline Anacardiaceae & $\begin{array}{l}\text { Searsia dentata } \\
\mathrm{x} \text {-axis } \\
\mathrm{y} \text {-axis }\end{array}$ & Ellipsoid & $\begin{array}{l}26.95 \\
22.13\end{array}$ & 0.018 & 0.018 \\
\hline Commelinaceae & $\begin{array}{l}\text { Commelina type } \\
\mathrm{x} \text {-axis } \\
\mathrm{y} \text {-axis }\end{array}$ & Ellipsoid & $\begin{array}{l}43.33 \\
28.61\end{array}$ & 0.037 & 0.037 \\
\hline Podocarpaceae & $\begin{array}{l}\text { Podocarpus latifolius } \\
\mathrm{x} \text {-axis } \\
\mathrm{y} \text {-axis }\end{array}$ & Ellipsoid & $\begin{array}{l}68.52 \\
38.19\end{array}$ & 0.074 & 0.074 \\
\hline Pinaceae & $\begin{array}{l}\text { Pinus patula } \\
\mathrm{x} \text {-axis } \\
\mathrm{y} \text {-axis }\end{array}$ & Ellipsoid & $\begin{array}{l}64.94 \\
37.20\end{array}$ & 0.073 & 0.073 \\
\hline Rosaceae & $\begin{array}{l}\text { Leucosidea sericea } \\
\mathrm{x} \text {-axis } \\
\mathrm{y} \text {-axis }\end{array}$ & Ellipsoid & $\begin{array}{l}29.51 \\
17.98\end{array}$ & 0.016 & 0.016 \\
\hline \multirow[t]{2}{*}{ Cyperaceae } & $\begin{array}{l}\text { Carex austro-africana } \\
\mathrm{x} \text {-axis } \\
\mathrm{y} \text {-axis }\end{array}$ & Ellipsoid & $\begin{array}{l}38.49 \\
30.26\end{array}$ & 0.035 & 0.036 \\
\hline & $\begin{array}{l}\text { Fionia type } \\
\mathrm{x} \text {-axis } \\
\mathrm{y} \text {-axis }\end{array}$ & Ellipsoid & $\begin{array}{l}37.17 \\
25.39\end{array}$ & 0.037 & \\
\hline
\end{tabular}




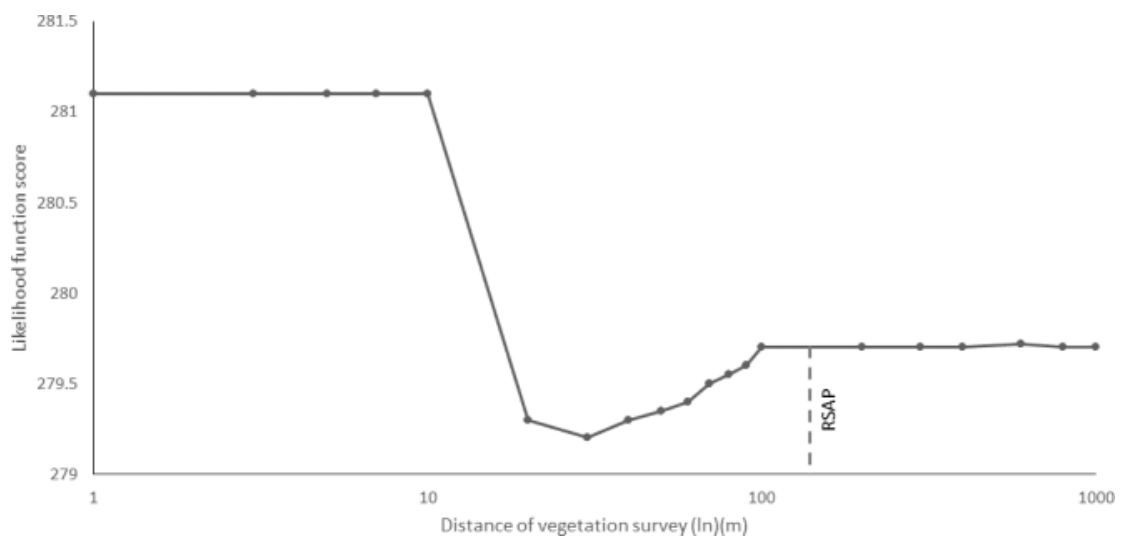

Figure 3. ERV analysis output for RSAP estimations. Illustrated are likelihood function score graphs for pollen-vegetation datasets run with Sutton's taxon specific distance-weighting using ERV model 1. RSAP is visually estimated from the graphs where the curve tends to an asymptote. While the maximum vegetation survey distance was $5000 \mathrm{~m}$, a logarithmic scale was used to $1000 \mathrm{~m}$ from sample points as an asymptote had been reached by this distance.

Table 3. Calculated RPP estimates for taxa selected from sampled sites. All values indicated are unit-less ratios relative to a reference taxon, where $\mathrm{RPP}=1$. TT $=$ Themed $a$ grassland, $\mathrm{PS}=$ Prote $a$ savanna, $\mathrm{LS}=$ Leucosidea scrubland.

*Taxon family names used in ERV analysis: Poa = Poaceae, Aster = Asteraceae, Pteri $=$ Pteridophyte, Podo $=$ Podocarpaceae, Prot $=$ Proteaceae, Rosa $=$ Rosaceae, Erica $=$ Ericaceae.

\begin{tabular}{lllllllll}
\hline & & \multicolumn{7}{c}{ PPE } \\
\cline { 4 - 9 } $\begin{array}{l}\text { Vegetation } \\
\text { type }\end{array}$ & $\begin{array}{l}\text { ERV } \\
\text { model }\end{array}$ & Poa & Aster & Pterio & Podo & Prot & Rosa & Erica \\
\hline Themeda & 1 & 1 & 0.00015 & 4.60171 & - & - & - & - \\
triandra & 2 & 1 & 0.00026 & 3.14094 & - & - & - & - \\
Protea savanna & 1 & 1 & 0.00038 & 8.49329 & 6.54313 & 0.22356 & - & - \\
& 2 & 1 & 0.00057 & 9.51827 & 5.13538 & 0.00050 & - & - \\
Leucosidea & 1 & 1 & - & 25.71204 & - & - & 3.33815 & 0.80950 \\
sericea & 2 & 1 & - & 12988 & - & - & 7291 & 743 \\
\hline
\end{tabular}

In the Themeda grassland, Asteraceae pollen $\left(\mathrm{RPP}_{\text {Poaceae }}=0.00026\right)$ producing plant species are substantially less productive in terms of pollen production than grasses, whereas Pteridophyte $\left(\mathrm{RPP}_{\text {Poaceae }}=3.14\right)$ are significantly higher producers. In the Protea savanna, Asteraceae pollen $\left(\mathrm{RPP}_{\text {Poaceae }}=0.00038\right)$ and Proteaceae pollen $\left(\mathrm{RPP}_{\text {Poaceae }}=0.22\right)$ producing plant species are less productive in terms of pollen production than grasses, whereas Pteridophyte $\left(\mathrm{RPP}_{\text {Poaceae }}=8.49\right)$ and Podocarpaceae pollen $(\mathrm{RPP}$ Poaceae $=6.54)$ producing species are significantly higher producers. RPP estimates obtained for the Leucosidea scrubland show Ericaceae pollen $\left(\mathrm{RPP}_{\text {Poaceae }}=0.81\right)$ producing plant species are less productive, whereas Pteridophyte $\left(\mathrm{RPP}_{\text {Poaceae }}=25.71\right)$ and Rosaceae $\left(\mathrm{RPP}_{\text {Poaceae }}=3.34\right)$ are higher palynomorph producers (Table 2). 


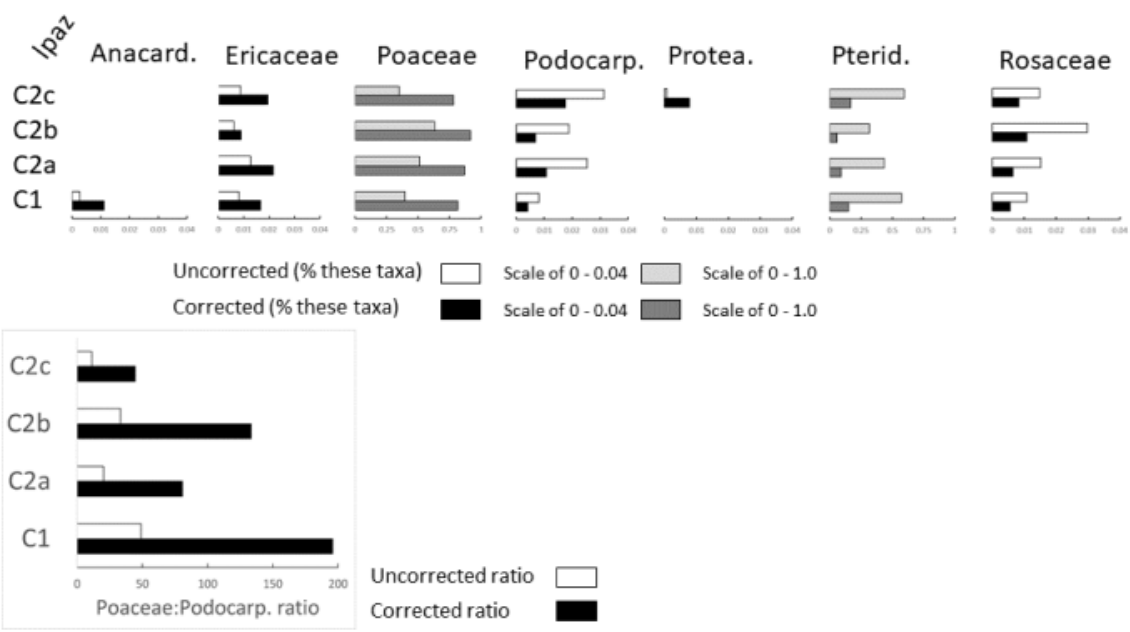

Figure 4. Original and RPP-corrected pollen data for the four pollen zones from the Cathedral Peak Wetland pollen diagram (Lodder et al. 2018). (A) comparison of uncorrected and corrected values for 7 taxa (Table 1 other than Asteraceae - see text for details) - note variable x-axis scale. (B) Poaceae:Podocarpaceae ratio (an index of landscape openness).

\subsubsection{Application of RPP values to palaeoecological data}

Counts of the taxa listed in Table 1 made up $60-74 \%$ of the total pollen count - Cyperaceae (a local wetland taxon which dominates the pollen diagram; Lodder et al. 2018) of the four pollen zones from the Cathedral Peak Wetland. Figure 4 ( $a$ and $b$ ) shows the results of correction with Asteraceae excluded, since some Asteraceae may be local wetland vegetation; correction increases the apparent abundance of Poaceae, Ericaceae, Anacardaceae and Proteaceae, and reduces the apparent abundance of Podocarpaceae, Proteaceae and Rosaceae. An example of the importance of considering RPP when interpreting fossil pollen data is given by the ratio between Poaceae and Podocarpaceae pollen (Figure 4b). Podocarpaceae are forest taxa with well dispersed pollen, whilst Poaceae dominate grasslands and rarely flower under forest canopies, therefore this ratio provides an indication of the balance between open grassland and forested areas in the wider landscape. Without weighting, the ratio ranges from 11 to 49 between zones, whilst with the weighting included, values range from 44-196, giving a different impression of the role of forest in the wider landscape.

\subsection{DISCUSSION}

\subsubsection{Vegetation data}

The vegetation survey method and distance-weighting methods used allocates surveyor effort according to the relative importance of plants as potential pollen sources for the sample location, since plants closer to a sample site contribute more directly to the pollen signal than those further away. The dominant species recorded were as expected for the plant communities mapped in the area. 


\subsubsection{Pollen data}

Pollen assemblages from all surface samples were dominated by Poaceae, reflecting the general character of the research area. Bracken fern was pervasive throughout all environments, and this was recorded by high spore counts.

\subsubsection{Data analysis - estimates of RSAP and PPE}

RSAP values are similar in all three communities, with estimates ranging between 100-150 m, suggesting that the variation in pollen signal between sample locations in each community is controlled by vegetation composition and distribution within a 100-150 m radius of the sample point (Sugita 1994).

Where a taxon appears in more than one community, the absolute RPP values obtained differ, however the rank of taxon RPP relative to Poaceae is consistent, suggesting that despite the small number of samples included, real features of the pollen vegetation relationship are being reliably detected by the analysis which can be used as the basis for future interpretation of pollen records.

Asteraceae is under-represented compared to Poaceae in both the Themeda grassland samples and the Protea savannah, Proteaceae are under-represented in Themeda grassland and Ericaeae are under-represented in Leucosidea scrubland. Pteridophyta are over-represented in all three habitats, whilst Podocarpaceae are over-represented in Protea savannah and Rosaceae are over-represented in Leucosidea scrubland.

Duffin and Bunting (2008) adopted the same approach to analyse modern pollen spectra from 34 surface sediment samples in the Kruger National Park and present RPP values. The RSAP for all sites was estimated at $700 \mathrm{~m}$, which is considerably greater than the $150 \mathrm{~m}$ found in this study, however that is expected as Duffin and Bunting (2008) sampled small ponds rather than soil samples (e.g. Sugita 1994). RSAP differences could be partially attributed to the different sampling strategies in zones A and B of the vegetation surveys done between the two research projects or due to the differences in the Kruger National Park landscape and the topographical complexity of Cathedral Peak (Gaillard et al. 2008).

The taxa studied by Duffin and Bunting (2008), other than Poaceae, were different from those presented here. Combining the results (Table 4) and rounding RPP values, which is appropriate given the uncertainties associated with both studies, forms a useful basis for simulation studies and land cover reconstruction in advance of more detailed modern pollen studies in the region.

Results of analysis were considered more robust when using ERV model 1 rather than ERV model 2. In theory both models should be equivalent, however model 1 assumes that the taxon-specific background pollen (pollen travelling from beyond the RSAP) is constant relative to the total influx of pollen at the sample location, whereas model 2 assumes that the component is constant relative to the total vegetation abundance around the site. In landscapes with discontinuous vegetation cover, it can be argued that the model 1 assumption is more justifiable, which would accord with the results presented here.

\subsubsection{Implications of findings for palaeoecological research in the region}

The set of RPP values presented in Table 3 are an essential first step for the application of pollen-vegetation model-based reconstruction approaches in the region. For detailed landcover reconstruction, the next step is to compile all available pollen records and, where gaps exist, to seek out suitable sedimentary archives. One small wetland record in the KwaZulu-Natal Drakenberg area has produced a pollen record (Lodder et al. 2018) and a simple demonstration of how interpretation of the record can be altered by using RPP values to adjust the pollen counts taking into account differential pollen production presented in Figure 4. 
Table 4. Pollen productivity and fall speed estimates for taxa in South Africa; RPP estimates rounded to powers of 2.

\begin{tabular}{llll}
\hline Taxon & $\begin{array}{l}\text { RPP } \\
\text { (categorised) }\end{array}$ & $\begin{array}{l}\text { Fallspeed } \\
\text { estimate }\left(\mathrm{ms}^{-1}\right)\end{array}$ & Source \\
\hline Acacia-type & 0.5 & 0.096 & Duffin and Bunting (2008) \\
Anacardiaceae & 0.5 & 0.019 & Duffin and Bunting (2008) \\
Asteraceae & 0.01 & 0.026 & This study \\
Colophospermum mopane & 0.25 & 0.042 & Duffin and Bunting (2008) \\
Combretaceae & 0.5 & 0.014 & Duffin and Bunting (2008) \\
Ericaceae & 1.0 & 0.077 & This study \\
Podocarpaceae & 4.0 & 0.074 & This study \\
Protea & 0.25 & 0.017 & This study \\
Pteridophyte spores & 8.0 & 0.044 & This study \\
Rosaceae & 4.0 & 0.016 & This study \\
\hline
\end{tabular}

\subsubsection{Limitations and future direction}

Soil pollen assemblages are considered to be relatively poor analogues for the pollen trapping properties of the sedimentary sequences palaeoecologists use for reconstruction compared to moss or lake sediment samples (e.g. Adam and Mehringer 1975; Li et al. 2018), but are often the only natural option in savannah and grassland environments. Future studies using a larger number of samples, or including pollen trap studies and surface sediment studies, would enable more robust conclusions to be drawn. However, the consistency of the results presented here, between the different communities, suggests that despite small numbers of samples the results do reflect meaningful properties of the studied ecosystem, allowing us to present initial values to support simulation studies and landcover reconstruction in the region. Balancing effort/cost with outcomes is a known and challenging issue in modern pollen studies, but the implications of being able to better translate pollen assemblages into past land cover demonstrate the incentive to continue to work.

\subsection{CONCLUSIONS}

Modern pollen and vegetation data from three dominant vegetation communities in the KwaZuluNatal Drakensberg were collected and analysed, producing estimates of RSAP (100-150 m) and RPP for the dominant palynomorph-equivalent taxa in three communities, Themeda grassland, Protea savanna and Leucosidea scrubland. Interpretation of ERV results has shown that, while the model outputs are not 'perfect' as would be the case in an open, homogeneous and flat landscape, they are perfectly coherent and within the realm of expectations of results from a study with a relatively small amount of samples in a varied landscape. The findings of this study are therefore that developments made in pollen modelling have a very relevant place in South African pollen research and can significantly impact future work by strengthening the foundation from which we base our understanding - the interpretation of results.

The results, combined with the findings of Duffin and Bunting (2008), form a solid basis for the application of simulation and landcover reconstruction approaches in the KwaZulu-Natal Drakensberg area, which is an area possessing rich archaeological and palaeo-ecological archives. Further validation of these models in South African pollen research can only further serve to improve our confidence in pollen data, and it is the hope that this research has in the very least 
informed and sparked interest for future researchers in this new and significant aspect in pollen science.

\section{ACKNOWLEDGEMENTS}

To the University of KwaZulu-Natal Geography Department for the use of field equipment and laboratory space. Ezemvelo KZN Wildlife for agreeing to allow the research be conducted in Cathedral Peak Research Station. This research was supported by financial assistance from the National Research Foundation.

\section{REFERENCES}

Abraham, V. and Kozáková, R., 2012, Relative pollen productivity estimates in the modern agricultural landscape of Central Bohemia (Czech Republic). Review of Palaeobotany and Palynology, 179, pp. 1-12, 10.1016/j.revpalbo.2012.04.004.

Adam, D.P. and Mehringer, P.J., 1975, Modern pollen surface samples - an analysis of subsamples. Journal of Research of the U.S. Geological Survey, 3(6), pp. 733-736.

Andersen ST (1970) The relative pollen productivity and pollen representation of northEuropean trees, and correction factors for tree pollen spectra. Danmarks Geologiske Undersogelse, 96, pp.1-99.

Broström, A., 2002, Estimating source area of pollen and pollen productivity in the cultural landscapes of southern Sweden - developing a palynological tool for quantifying past plant cover. LUNDQUA Thesis 46. Department of Geology, Lund University, Lund.

Broström, A., Sugita, S. and Gaillard, M.-J., 2004, Pollen productivity estimates for the reconstruction of past vegetation cover in the cultural landscape of southern Sweden. The Holocene, 14(3), pp. 368-381, 10.1191/0959683604hl713rp.

Broström, A., Sugita, S. and Gaillard, M.-J., 2005, Estimating the spatial scale of pollen dispersal in the cultural landscape of southern Sweden. The Holocene, 15, pp. 252-262, 10.1191/0959683605hl790rp.

Bunting, M.J., 2008, Pollen in wetlands: using simulations of pollendispersal and deposition to better interpret the pollen signal. Biodiversity and Conservation, 17, pp. 2079-2096, 10.1007/s10531-007-9219-x.

Bunting, M.J., Armitage, R., Binney, H.A. and Waller, M., 2005, Estimates of "relative pollen productivity" and "relevant source area of pollen" for major tree taxa in two Norfolk (UK) woodlands. The Holocene, 15, pp. 459-465, 10.1191/0959683605hl821rr.

Bunting, M.J., Farrell, M., Broström, A., Hjelle, K.L., Mazier, F., Middleton, R., Nielsen, A.B., Rushton, E., Shaw, H. and Twiddle, C.L., 2013, Palynological perspectives on vegetation survey: a critical step for model-based reconstruction of Quaternary land cover. Quaternary Science Reviews, 82, pp. 41-55, 10.1016/j.quascirev.2013.10.006.

Bunting, M.J. and Hjelle, K.L., 2010, Effect of vegetation data collection strategies on estimates of relevant source area of pollen (RSAP) and relative pollen productivity estimates (relative PPE) for non-arboreal taxa. Vegetation History and Archaeobotany, 19, pp. 365-374, 10.1007/s00334-010-0246-2.

Chevalier, M., Cheddadi, R., and Chase, B.M., 2014, CREST (Climate REconstruction SofTware): A probability density function (PDF)-based quantitative climate reconstruction method. Climate of the Past, 10, pp. 2081-2098, 10.5194/cp-10-2081-2014.

Chevalier, M., Chase, B.M., Quick, L.J., Dupont, L.M. and Johnson, T.C., 2021. Temperature change in subtropical southeastern Africa during the past 790,000 yr. Geology, 49(1), pp.71-75, 10.1130/G47841.1. 
Davis, M.B., 1963, On the theory of pollen analysis. American Journal of Science, 261, pp.897912, 10.2475/ajs.261.10.897.

Davis, M.B., 2000, Palynology after Y2K-Understanding the Source Area of Pollen in Sediments. Annual Review of Earth and Planetary Sciences, 28, pp. 1-18, 10.1146/annurev. earth.28.1.1.

Duffin, K.I. and Bunting, M.J., 2008, Relative pollen productivity and fall speed estimates for southern African savanna taxa. Vegetation History and Archaeobotany, 17, pp. 507-525, 10.1007/s00334-007-0101-2.

Gaillard, M-J., Sugita, S., Bunting, M.J., Middleton, R., Broström, A., Caseldine,C., Giesecke, T., Hellman, S.E.V., Hicks, S., Hjelle, K., Langdon, C., Nielsen, A.B., Poska, A., von Stedingk, H., Veski, S. and POLLANDCAL members, 2008, The use of modelling and simulation approach in reconstructing past landscapes from fossil pollen data: a review and results from the POLLANDCAL network. Vegetation History and Archaeobotany, 17, pp. 419-443, 10.1007/s00334-008-0169-3.

Githumbi, E.N., Courtney, C.J. and Marchant, R., this volume sedimentological, palynological and charcoal analyses of the hydric palustrine sediments fromthe lielerai-kimana wetlands, kajiado, southern kenyA. Palaeoecology of Africa, 35, chapter 8, 10.1201/9781003162766-8.

Gregory, P.H., 1973, The microbiology of the Atmosphere. 2nd ed. Leonard Hill, Aylesbury.

Hill, T., 1996, Description, classification and ordination of the dominant vegetation communities, Cathedral Peak, KwaZulu-Natal Drakensberg. South African Journal of Botany, 62(5), pp. 263 269, 10.1016/S0254-6299(15)30655-4.

Hjelle, K., 1998, Herb pollen representation in surface moss samples from mown meadows and pastures in western Norway. Vegetation History and Archaeobotany, 7, pp. 79-96, 10.1007/BF01373926.

Jackson, S.T., 1994, Pollen and spores in Quaternary lake sediments as sensors of vegetation composition: theoretical models and empirical evidence. In: Sedimentation of Organic Particles, edited by Traverse, A., (Cambridge: Cambridge University Press).

Jackson, S.T. and Lyford, M.E., 1999. Pollen dispersal models in Quaternary plant ecology: assumptions, parameters, and prescriptions. The Botanical Review, 65(1), pp.39-75, 10.1007/BF02856557.

Jolly, D., Prentice, I.C., Bonnefille, R., Ballouche, A., Bengo, M., Brenac, P., Buchet, G., Burney, D., Cazet, J.P., Cheddadi, R. and Edorh, T., Elenga, H., Elmoutaki, S., Guiot, J., Laarif, F., Lamb, H., Lézine, A.-M., Maley, J., Mbenza M., Peyron, O., Reille, M., Reynaud-Farrera, I., Riollet, G., Ritchie, J.C., Roche, E., Scott, L., Ssemmanda, I., Straka, H., Umer, M., Van Campo, E., Vilimumbalo, S., Vincens, A.andWaller, M., 1998, Biome reconstruction from pollen and plant macrofossil data for Africa and the Arabian peninsula at 0 and 6000 years. Journal of Biogeography, 25(6), pp.1007-1027, 10.1046/j.1365-2699.1998.00238.x.

Li. F., Gaillard, M.-J., Xu, Q., Bunting, M.J., Li, Y., Li, J., Mu, H., Lu, J., Zhang, P., Zhang, S., Cui, Q., Zhang, Y., and Shen, W., 2018, A review of relative pollen productivity estimates from temperate China for pollen-based quantitative reconstruction of past plant cover. Frontiers in Plant Science, 9, article: 1214, 10.3389/fpls.2018.01214.

Mazier, F., Broström, A., Gaillard, M-J., Sugita, S., Vittoz, P. and Buttler, A., 2008, Pollen productivity estimates and relevant source area of pollen for selected plant taxa in a pasture woodland landscape of the Jura Mountains (Switzerland). Vegetation History and Archaeobotany, 17, pp. 479-495, 10.1007/s00334-008-0143-0.

Mazier, F., Gaillard, M.J., Kuneš, P., Sugita, S., Trondman, A.K. and Broström, A., 2012, Testing the effect of site selection and parameter setting on REVEALS-model estimates of plant abundance using the Czech Quaternary Palynological Database. Review of Palaeobotany and Palynology, 187, pp. 38-49, 10.1016/j.revpalbo.2012.07.017.

Mitchell, P.J. and Lane, P., 2013, The Oxford Handbook of African Archaeology. (New York: Oxford University Press). 
Moore, P.D., Webb, J.A., Collinson, M.E., 1991, Pollen Analysis. 2nd edition, (Oxford: Blackwell Scientific Publications).

Mucina, L., Rutherford, M.C., 2011, The Vegetation of South Africa, Lesotho and Swaziland. Strelitzia, Volume 19, (Pretoria: South African National Biodiversity Institute).

Nielsen, A.B., 2003, Pollen-based quantitative estimation of land cover-relationships between pollen sedimentation in lakes and land cover as seen on historical maps in Denmark A.D. 1800. PhD Thesis. University of Copenhagen, Denmark.

Prentice, I.C., 1985, Pollen representation, source area, and basin size: Toward a unified theory of pollen analysis. Quaternary Research, 23, pp. 76-86, 10.1016/0033-5894(85)90073-0.

Prentice, I.C., 1988, Records of vegetation in time and space: the principles of pollen analysis. In Vegetation History, edited by Huntley, B. and Webb, T.III, (Dordrecht: Kluwer Academic Publishers), pp. 17-42.

Räsänen, S., Suutari, H. and Nielsen, A.B., 2007, A step further towards quantitative reconstruction of past vegetation in Fennoscandian boreal forests: Pollen productivity estimates for six dominant taxa. Review of Palaeobotany and Palynology, 146, pp. 208-220, 10.1016/j.revpalbo.2007.04.004.

Soepboer, W., Sugita, S., Lotter, A.F., van Leeuwen, J.F.N. and van der Knaap, W.O., 2007, Pollen productivity estimates for quantitative reconstruction of vegetation cover on the Swiss plateau. The Holocene, 17(1), pp. 65-77, 10.1177/0959683607073279.

Sokal, R.R. and Rohlf, F.J., 1969, Biometry: The Principles and Practice of Statistics in Biological Research, 4th edition, (New York: W.H Freeman and Company).

Sugita, S., 1993, A model of pollen source area for an entire lake surface. Quaternary Research, 39, pp.239-244, 10.1006/qres.1993.1027.

Sugita, S., 1994, Pollen representation of vegetation in Quaternary sediments: theory and method in patchy vegetation. Journal of Ecology, 82, pp. 881-897, 10.2307/2261452.

Sugita, S., 2007a, Theory of quantitative reconstruction of vegetation I: Pollen from larges sites REVEALS regional vegetation composition. The Holocene, 17(2), pp. 229-241, $10.1177 / 0959683607075837$.

Sugita, S., 2007b, Theory of quantitative reconstruction of vegetation II: All you need is LOVE. The Holocene, 17(2), pp. 243-257, 10.1177/0959683607075838.

Sugita, S., Gaillard, M-J. and Broström, A., 1999, Landscape openness and pollen records: a simulation approach. The Holocene, 9, pp. 409-421, 10.1191/095968399666429937.

Vincens, A., Bremond, L., Brewer, S., Buchet, G. and Dussouillez, P., 2006, Modern pollen-based biome reconstructions in East Africa expanded to southern Tanzania. Review of Palaeobotany and Palynology, 140(3-4), pp.187-212, 10.1016/j.revpalbo.2006.04.003.

von Stedingk, H., Fyfe, R. and Allard, A., 2008, Pollen productivity estimates for the reconstruction of past vegetation at the forest-tundra ecotone. The Holocene, 18, pp. 323-332, $10.1177 / 0959683607086769$. 